\title{
WORKING-CLASS HIGH SCHOOL LEARNERS' CHALLENGE TO CHANGE: INSIGHTS FROM THE EQUAL EDUCATION MOVEMENT IN SOUTH AFRICA ${ }^{1}$
}

\section{Steven Lance Robins}

University of Stellenbosch

Email: robins@netactive.co.za

\section{Brahm Fleisch}

University of the Witwatersrand

Email: brahm.fleisch@wits.ac.za

\section{ABSTRACT}

Hargreaves (2002) suggested that vigorous social movements have the potential to improve the quality of (and increase the equity in) public education. This paper explores the role of Equal Education, an education social movement in South Africa led by university students and secondary school learners, in the process

1. Interview evidence presented in this paper was also used in Brahm Fleisch and Steven Robins, Mediating active citizenship and social mobility in working-class schools: The case of Equal Education in Khayelitsha, Cape Town. In Citizenship as mediation: The role of intermediaries in relations between states and poor \& marginalised groups in the Global South, edited by Laurence Piper and Bettina Von Lieres, (Palgrave 2014).
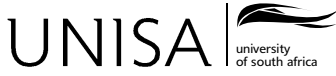

Education as Change Volume 20 | Number 2 | 2016 | pp. 145-162 www.educationaschange.co.za

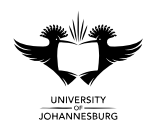

DOI: http://dx.doi.org/10.17159/1947-9417/2016/877 Print ISSN 1682-3206 | Online 1947-9417

(C) 2016 The Author(s) 
of educational change. Drawing on interviews with the organisation's founding members, organisers and secondary school learners, the paper examines how the organisation/social movement embodies what Oakes and Rogers (2007) describe as 'learning power' and in the process contribute to improvement in public education.

Keywords: Educational change; social movements; learning power

\section{INTRODUCTION}

Over a decade ago, Hargreaves (2002) suggested that vigorous social movements have the potential to improve the quality of (and increase the equity in) public education. This is of course not a new idea, and we have seen numerous education social movements over the past century. Drawing on the impact that more recent social movements have had on environmental politics, global peace initiatives and efforts to combat gender inequality, Hargreaves suggests that social movements because they are typically not driven by the logic of the market or dependencycreating states - can challenge the order of things. He offers two reasons for this: first, social movements are often uncompromising; their principles tend not to be sullied by short-term compromises and second, they move in glacial time and are not wedded to the short electoral cycles. While Hargreaves's perspective might be a little romantic, his insights about the movements as agents of change is an important contribution. In recent years research on social movements in the field of social justice and education has expanded and deepened, with important contributions by scholars such as Oakes and Rogers $(2006 ; 2007)$ and Shirley $(1997 ; 2009)$. Oakes and Rogers $(2006$; 2007) make the point that social movements concerned with educational change can make a significant impact when they focus on 'learning power; These kinds of interventions may allow social movements to become both the catalyst and the crucible for substantive social justice change.

In the case of South Africa, early 2015 witnessed the spectacular explosion of militant student movements on campuses that challenged what the students deemed to be institutional racism and a general lack of tertiary sector transformation. These national protests began when student leaders at the University of Cape Town demanded the removal of colonial names of buildings and the Cecil John Rhodes statue from the campus. The 2015 Rhodes Must Fall campaign at UCT also included demands for wider changes such as curriculum reforms that better reflected African realities and epistemological traditions, affirmative action and, later that year, the elimination of fee increases. In late October 2015, nationwide student actions against fee increases culminated with the 'storming' of Parliament's gates and a massive student protest at the seat of the executive at the Union Buildings in Pretoria. The state's response to this nationwide mobilisation was to freeze fee increases for 
2016 and to set up a commission to examine the financial feasibility of free tertiary education.

Prior to the eruption of these protests, a Cape Town-based social movement called Equal Education had been working for over seven years to improve public education. This movement's campaigns included mobilising school learners through leadership training as well as social audits of school infrastructure to pressure, lobby, blame and shame the state into providing better facilities at poorly resourced public schools. The EE also campaigned to force the state to establish national norms and standards for school infrastructure such as libraries and toilets. Rather than deploying the spectacular politics of the 2015 university students, these secondary school education activists deployed what we refer to as more long-term organisational forms of 'slow activism' (Robins 2014). As will become clear in this paper, the tactics deployed by EE to improve and reform public education appear to differ markedly from the spectacular protests of the university students in 2015. But what they may lack in spectacularity, they make up for in their sustained engagement with education improvement.

Theorists on social movements in South Africa routinely reproduce stark oppositions between 'radical' social movements that embrace the spectacular revolutionary politics of the barricades, and those that are perceived to work within the 'reformist' logic of the law, 'NGOism', liberalism, constitutional democracy and the bureaucratic state (see Robins, 2008). These strikingly different activist strategies also seem to manifest as contrasts between the politics of the instant media spectacle and the patient, long-term organisational work of 'slow activism'. But this contrast between the slow and patient style of EE activism and the politics of the burning barricades typically associated with 'service delivery' protests and labour strikes may be overstated. By examining the everyday practices of EE we aim to explore how education activists work with these twin logics of spectacle and slow activism.

Unlike much of the literature on social movements and education change, this case study attempts to understand the significance of an education social movement in the setting of the Global South. It is specifically concerned with how Equal Education (EE) has used the courts, petitions, rallies, protests outside Parliament, mass media, new social media, alliances with trade unions as well as access to education professionals and state officials, and grassroots mobilisation in high schools and universities in the course of ongoing, long-term struggles for improved public schooling. The campaigns that this organisation has initiated range from localised struggles to have broken classroom windows in urban working-class high schools repaired, struggles to pressure provincial governments to build school libraries, and battles to ensure that teachers and learners arrive at school punctually to wider engagements aimed at changing national regulations. Media-friendly public spectacles involving sleeping outside of Parliament to highlight the state's refusal to introduce norms and standards for public school infrastructure, and the public 
performance of ritualised 'insults', criticism and humiliation of the Minister of Education are also part of their activist repertoire. At the same time this movement has developed a critical pedagogy: a version of 'learning power' concerned with establishing the rights of citizens in poor neighbourhoods to mobilise for decent public schooling. The EE mobilisation efforts in the Western Cape Province that we focused on involved secondary school learners in under-resourced schools in the predominantly isiXhosa township of Khayelitsha in Cape Town. These are the learners who act as mediators of the pedagogy of active citizenship that is at the heart of this rights-based social movement.

In this paper we begin by examining the politics of an education social movement and end by exploring the implications for leaders who align themselves with a social justice project. We do this by means of an exploration of the life histories of a small group of learner leaders. We focus explicitly on 'rights talk', and how these learner leaders perceive their engagement as tipping the national education agenda in favour of poor and working-class communities.

\section{THEORETICAL CONSIDERATIONS}

In an extensive review of the social movement literature, Marc Edelman (2001, 285 ) notes that theories of collective action have undergone a number of paradigm shifts - from 'mass behaviour' to 'resource mobilisation', 'political processes', and 'new social movements'. Edelman argues that in the 1970s theorists of new social movements sought to address a number of conceptual conundrums and theoretical blind spots of earlier approaches - in particular the functionalist and rational actor orientation of these approaches. Edelman identifies Alain Touraine $(1981 ; 1985)$ as one of the first scholars to theorise the emergence in Europe in the 1970s and 1980s of the 'new' environmentalist movements, such as peace and anti-nuclear, women's, gay liberation, minority rights, and learner and youth movements (see also Melucci 1989). Since then the list of new movements has grown to include struggles for human rights and democratisation, the rights of indigenous peoples and the needs of the rural landless and urban slum dwellers.

Literature specifically dealing with social movements/community organising and education change draws on the debates that have taken place in the wider literature. Shirley (2009), reviewing the shifts that have taken place in the field of community organising and education, makes a convincing case that scholarship in this area has expanded dramatically in the past decade. This is evidenced in the work of Mark Warren, Milbery McLaughlin, Jeannie Oakes and colleagues, scholars at the Annenberg Institute at Brown University. Shirley makes the point that the scholarship has shifted from case study analyses that provide vivid accounts of specific struggles toward new research that contributes to an understanding of the impact of new civic struggles on local and system educational change. 
Important conceptual developments have also taken place. Understanding the generative mechanisms linking local and system struggles to sustained equityoriented educational change, Oakes and Rogers (2006) provided a theoretical account that turns on the key concept of 'learning power'. For Oakes and Rogers, the 'learning power' has three distinct but interdependent components. These are 'learning about power', the 'power of learning', and 'learning to be powerful'. From the LA community network case study, Oakes and Rogers describe how activists learn to do 'power maps' that allow them to identify and evaluate who has the power to grant or deny their demands as they campaign for better schools. The 'power of learning' involves participatory research that produces knowledge critical for the change process. Finally, 'learning power' involves 'learning to be powerful', i.e. building networks and alliances and learning how to occupy and control spaces of power. Warren and Mapp (2011), in their book on community organising in education change, provided a theoretical framework that begins with an analysis of the roots of community organising and proceeds to unpack the processes and impact of change for individuals, communities and organisations.

While the research on civic engagement (both social movements and community organising) and educational change provide us with better understanding of opportunities, framing, resources, organisation and identity, a key social tension or even class contradiction has been inadequately explored. This social tension/ class contradiction was magnified in South African struggles of the 1980s. During the anti-apartheid movement in South Africa, social justice activists, through their involvement in anti-apartheid social movements and community organising, acquired forms of political literacies that allowed them to enter into the elite spaces of 'civil society' (see Robins 2008). What we are particularly interested in in this paper is how these political literacies are mediated through everyday pedagogical and organisational practices that we refer to as slow activism. Slow activism, we argue, can be contrasted with the politics of the barricades and the instant media spectacle. But, rather than viewing these as diametrically opposed and mutually incompatible political logics, we are interested in the ways in which these twin logics operate in the everyday political practices of social movements such as EE. In particular, how social activists engage with both the need for slow and patient forms of organisational work and the need for a politics of legibility, whereby certain issues such as structural violence and systemic inequalities in health, schooling and sanitation, are often not visible in the media and in public political discourse.

Rob Nixon's (2011) Slow Violence and the Environmentalism of the Poor is specifically concerned with the representational difficulties resulting from long-term environmental catastrophes that do not conform to the media spectacles of instant suffering and humanitarian crisis. ${ }^{2}$ Nixon uses the concepts of 'slow violence' and

2 Rob Nixon, Slow Violence and the Environmentalism of the Poor (Cambridge, Mass. \& London: Harvard University Press, 2011). 
'slow dyings' to refer to disasters such as Chernobyl and Bophal where the lethal effects of contamination can unfold over several decades. These environmental catastrophes create challenges for writers and activists precisely because they are 'low in instant spectacle but high in long-term effects' (Nixon 2006, 15). Like slow violence, structural violence and chronic poverty present their own representational challenges. This paper is concerned with how EE develops its methodologies of slow activism that draw attention to the less visible aspects of education reform, such as inequalities in the distribution of toilets, libraries, laboratories and other infrastructure required for effective schooling. It is these slow and patient tactics of making educationally-related infrastructure politically legible that characterises EE's particular brand of slow activism. Having laid out the conceptual terrain for the paper, we will now turn our attention to specific ethnographic case material that illustrates how these forms of activism are actually practised.

\section{RATIONALE FOR CASE STUDY AND METHODOLOGICAL CONSIDERATIONS}

Although not unique internationally as a social justice organisation whose mission is to mobilise local, regional and national communities around a constitutional right to education (Robins 2008), Equal Education has a number of qualities that make it worth studying (this argument is developed in Fleisch and Robins 2014).

First, unusual amongst rights-based movements (although similar movements are emerging in Chile), it has consciously chosen to mobilise secondary school learners from poor and working-class households. Although the focus of mobilisation has been on this demographic category of working-class youth, as an organisation it has attracted a cross-class leadership.

The second distinguishing feature of EE relates to its emergence as a 'second generation' civil society movement that was built on the remarkable successes of an earlier partner movement, the Treatment Action Campaign (TAC). The TAC, which was established in Cape Town in 1998, drew in turn upon the activist repertoires of the African National Congress (ANC) and the United Democratic Front (UDF) - an umbrella body for anti-apartheid organisations in the 1980s (see Robins 2008; Mbali 2013). As such, extensive experience has been carried over to the new organisation and this has accelerated EE's strategic, tactical, financial, and logistics sophistication. EE has only existed for a few years but it has already developed into a successful grassroots movement based in Khayelitsha - the largest working-class township in Cape Town. Although it is still based in Khayelitsha and the Western Cape, it has established similar grassroots bases in other parts of the country. It has also developed powerful networks with other allied civil society and labour organisations and this has contributed towards raising its national profile. (In the past three months, 
loosely affiliated groups of learners calling themselves EE have engaged in more radical and less disciplined struggles in the Cape metropolis, News24, 2015).

EE has developed a series of principled approaches to struggle that includes nonviolent protest, an emphasis on long-term capacity-building amongst the emerging cadre of working-class youth leaders and an openness to external researchers, the universities, journalists and a wide range of other civil society organisations. Unlike some militant civic organisations, such as the South African Student Congress, that rely on the media spectacle of burning barricades or distributing trash, the EE and its partner organisations have developed distinct forms of organising and capacity building - what Robins (2014) refers to as 'slow activism'.

Finally, while Equal Education has come into being only in the past seven years, it has developed a rich multi-media footprint. Extensive archival film and video resources are available for public scrutiny on YouTube and it has an active website that provides regular documentation presenting the case for the organisation's campaigns. While few researchers have published articles about the organisation, it gets regular media coverage (e.g., op. ed. articles relating to its various campaigns).

For the purposes of the study, the researchers pursued both informal and formal data collection processes. We have attended a number of public conferences, campaigns and meetings hosted by the organisation. During these events, the researchers have interacted with a range of the organisation's leaders and rank-andfile members. One of the authors is currently supervising one of the Gauteng leaders' post-graduate research.

For the purpose of this paper, much of the data presented was based on a series of semi-structured interviews that took place between September and November 2012 and informal discussions with Gauteng based leaders between January and March 2015. The semi-structured interviews took place in Khayelitsha, Cape Town and were facilitated by staff at the EE Khayelitsha office. The interviews with the Equalisers (high school learners) and Organisers (university students) were approximately 45 minutes long, electronically recorded and transcribed. The interview questions were clustered into three sections. The first focused on the activists' families and school histories. The second focused on their engagement with Equal Education and their understanding of the role of the organisation in educational change and the third on their personal educational and career plans and aspirations. For the purposes of this paper, we concentrated on the first two sets of questions. All interviewees signed consent forms that guaranteed anonymity, explained the purpose of the study and how the findings would be used and explained their right to withdraw from the interview process at any point.

\section{A BRIEF HISTORY OF EQUAL EDUCATION}

As the Treatment Action Campaign (TAC), the most prominent post-apartheid social movement, began to mature as an organisation, some of its leaders explored the idea 
that the rights-based model of activism it had pioneered could be effectively utilised in the education sectors. The founder of the TAC, Zackie Achmat, was responsible for establishing the basic framework for Equal Education under the direction of a new board comprising high profile educationists, policymakers and education activists. The initial steps in the Equal Education history involved the recruitment of a younger generation of organisational leaders, the most prominent of whom were Yoliswa Dwane and Doron Isaacs, both former University of Cape Town (UCT) law students. The initial organisational focus of the newly appointed staff was on recruiting secondary school learners in the Cape Town township of Khayelitsha. After 2013 the focus shifted towards wider organisation and the opening of offices in other provinces. In the past two years, one of the key growth points for the organisation has been in the townships of Tembisa and Daveyton, near Johannesburg.

Before the organisation even began to plan its initial campaign, it began thorough research that involved observing schools, meeting learners informally in and around the schools and discussing the issues they encountered. Doron Isaacs (cited in Fleisch and Robins 2014) recalled:

The first of the two activities that we did was producing a weekly news wrap, which was like an email group of the stories involving education that we came across. It was a mailing list where we would just read everything that had been published on education and we summarised the articles. It was hardly a revolutionary activity. And then the second thing was observations to build up our own familiarity with the issues... We would go every morning and just sit in classrooms in four schools in Khayelitsha [and] the Western Cape Government allowed us to just sit there. We used to just go and join a class and we just did that for a couple of months. We obviously got to know learners, got to see what was happening, and we used to then like take notes and then meet and discuss what we had observed.

Although Khayelitsha had a history of militant student organisations dating from the 1970s, Equal Education differentiated itself from earlier student movements through its commitment to building mutually beneficial and constructive relationships with learners, parents, teachers and the wider community, as well as with the various institutions of the state, particularly the local district office and the provincial education department.

Drawing on youth programmes developed in faith-based youth groups, small groups of learners were persuaded to affiliate, and these groups began a diverse range of activities including a photographic project in which learner members were given cameras and encouraged to take photographs of the conditions in their schools. The outcome of this project was the first campaign, the 'Broken Window Campaign', centred at Luhlaza Secondary School in Khayelitsha. Learner members, under the guidance of organisers, planned a campaign to persuade the provincial education department to repair over 500 broken windows at the school. The campaign included meeting with school management, with the elected representative council of learners (RCLs), and writing letters to the provincial government. This was followed by a 
petition, which attracted considerable media attention, in which Equal Education was able to collect over 2000 signatures, including those of a number of prominent national figures. The petition activities culminated in a rally that was held outside the provincial education department's head office. Despite a hostile reception from some local education officials and local teacher unions, the campaign eventually convinced the provincial government to fix the windows and undertake a major upgrade of the school infrastructure. During the course of the campaign, the learner membership from schools throughout Khayelitsha grew, as did the regional profile of the organisation. Subsequent to the first campaign, the organisation began to expand beyond Khayelitsha. It opened branches in Bontehewel and Kraaifontein and began to initiate activities in Grahamstown, Johannesburg, Port Elizabeth, Potchefstroom, Polokwane and Tembisa.

Since 2009 Equal Education has assisted other schools in Khayelitsha by fixing leaking roofs and undertaking other small infrastructure projects. The next community-wide campaign focused on the problem of late-coming. It was a milestone in the organisation's history as it shifted the emphasis from simply pressuring the state to provide goods and services, to beginning to work with learners, parents and teachers on identifying the key issues that affected the quality of education. While Equal Education initially faced considerable hostility from some officials and principals, the members and organisers were able to conscientise large sections of the Khayelitsha community. The initial success of the late-coming campaign in Khayelitsha provided a springboard for the same campaign in other communities. Running parallel to these campaigns was the organisational demand for school libraries, which involved conventional activist protest tactics and activities more closely associated with volunteer/social welfare activities. As the organisation matured, the focus shifted from school and community issues to national policy demands, particularly addressing the inadequate infrastructure in the poorest provinces. In November 2013, Equal Education won a historic victory by pressuring the Minister of Basic Education to enact national Minimum Norms and Standards for School Infrastructure. In mobilising for these norms and standards, EE highlighted the fact that $93 \%$ of South Africa's 24,793 public schools had no libraries, almost 2,500 had no water supply, $46 \%$ still used pit latrines and 913 had no toilets at all. ${ }^{3}$

These developments demonstrated the capacity of the organisation to identify, translate and mediate demands for improved conditions in public schools. But these processes of 'learning power' and 'learning to be powerful' for learners did not end with infrastructure improvements. In another paper we (Fleisch and Robins 2014)

3 Mail and Guardian, (November 23, 2012): 14. The process of establishing adequate regulations for school infrastructure turned out to be a longer, more protracted legal battle. However, on 29 November 2013, the minister finally published regulations that specified the minimum norms and standards for school infrastructure. This was after a series of protracted court challenges and mass protests, including camping outside the courts. 
make the point that these processes also resulted in the mediation of ideas and practices relating to active citizenship, a challenge that is central to the objectives of EE and its partner organisations. The activists who become involved in these campaigns also learn certain activist literacies and skills that can be translated into a variety of institutional settings and which can in turn facilitate social mobility.

A particularly graphic example of the 'power of learning' was evident in the partner organisation, Ndifuna Ukwazi (NU). NU was established in 2011 in Cape Town with the specific aim of developing the political education and organising skills of activists from organisations such as EE, TAC and SJC. The NU public education programme, which was initiated by Zackie Achmat and Fatima Hassan, was conceived of in order to develop the capacities of a highly networked cadre of working-class civil society leaders. Activists use terms such as 'bridge' and 'platform' to describe their engagement with a critical pedagogy of rights and active citizenship to working-class citizens involved in struggles for better clinics, sanitation, schools and other state resources and services. The objectives of NU include developing organisational and logistic skills for running specific campaigns - for instance, to mobilise EE members to pressure the state to repair classroom windows and establish norms and standards for school infrastructure. NU is also concerned with developing the less tangible skills of political analysis, strategic thinking, and developing wider understandings of South African politics and history. It would seem that EE, like $\mathrm{NU}$, is concerned with developing both specific skills required for campaign work, as well as more generic leadership competencies.

\section{EQUALISERS AND ORGANISERS: WORKING-CLASS YOUTH AND WORKING-CLASS SCHOOLS}

From our interviews it emerged that most of the Equalisers and Organisers came from poor 'working-class' families, newly arrived from the rural province of the Eastern Cape, and were either first or second generation residents of Cape Town. While some of the young people came from households with members in formal employment, most were the sons and daughters of domestic workers, casual labourers or informal artisans. They all had strong links to rural communities and had some experience in moving back and forth between homesteads in the Eastern Cape and the townships in the Western Cape. They had in common a strong parental figure, a mother, grandmother or father who acted as a role model/moral authority in the lives of the young people. They had all experienced very poor education. A common theme was the description of attending school in dilapidated buildings - commonly referred to as 'mud schools' - and the daily experience of violence around the school perimeter. They all talked about the absence of qualified teachers during key secondary school years. From the accounts of the respondents, it would seem that the scenario of 
500 broken windows at the Luhlaza High School in Khayelitsha was a common experience of educational inequality.

The Organisers (university students) had much in common with the Equalisers (high school learners) in terms of class background and school experiences. Most of the Organisers had attended school in Khayelitsha, had been active in the organisation during their high school days, and had graduated into the role of Organiser as they progressed into higher education or adult life. It was the common experience of having been at under-resourced and poorly functioning working-class schools that created the conditions for their involvement with EE.

\section{EE organisational culture and learning power and activist strategies}

Most of the Equalisers and Organisers that we interviewed were recruited into EE as learners during the first wave of mobilisation around the 500 Broken Windows Campaign. We found that the longer they had been part of the organisation, the more likely it was that they would have acquired a more sophisticated understanding of the deeper political objectives and agendas of EE. For instance, Ayanda, who was only recruited to EE as a university student, sees the organisation's mission in terms of the rather limited objective of 'keeping learners off the street'. By contrast, Nkosi, who participated in the earlier EE activities while he was a learner, developed a very sophisticated political and class analysis of the education system. This broader political education presumably emerged from his reading group discussions and exposure to the inner workings of the organisation's leadership structures.

Lonwabo's introduction to rights-based politics was through a photography project. A group of volunteers agreed to take photographs of his school. The exercise required them to have a discussion about what pictures to take. This innovative photography project, which was sponsored by Equal Education, led Lonwabo to join the organisation with fourteen school friends. The key to his political development was meeting learners from other schools in Khayelitsha. During these meetings, he began to realise that the problems in his school were not unique, but that they were common problems experienced by all the secondary schools in the township. The specific issue that learners at his school (Chris Hani Secondary School) were concerned with was the absence of a Science teacher. The learners formed a crisis committee to deal with this issue. In 2008 Lonwabo joined the Leadership Committee and the following year was elected the chair of the committee. He successfully completed Grade 12 that year and began studying the following year at a local university. During his first year at university, he worked for Equal Education as a volunteer and was promoted the following year to the position of Organiser. Over time, the campaigns Lonwabo was involved in changed from school-based issues to wider national campaigns. In 2011 he played an important role in organising the Equal Education rally in Cape Town centre. 
Reflecting on his work in the organisation, Lonwabo described Equal Education as 'a bridge' connecting government to communities. He also used the metaphor of 'a platform': 'It gave us a platform to raise issues'. He illustrated how the 'bridge' and 'platform' metaphors worked in the Broken Window Campaign of 2008. The initial school activities took place separately in each institution, where the Equalisers would raise the issue that most concerned learners in a particular school. The Equalisers would then come up with ideas on how to improve their schools. At Luhlaza Secondary the issue emerged from a very provocative photograph taken by Zami V (one of the learners) of an entire bank of broken windows at the school. By engaging with the problem of broken windows, Equal Education aimed to provide a 'platform' on which learners could raise their grievances.

Lonwabo contrasted the EE experience with the 'disastrous' march led by an ANC-aligned student organisation, the Congress of South African Students (COSAS) in 2007 (Angara 2011). During that action, COSAS members entered a school and tore up learner exam papers, protesting the closure of an adult education centre. The COSAS action became a fundamental pedagogic 'object lesson' for EE. The COSAS action did not get any teacher or community support. The EE approach would be different in many respects. It would focus on making the community aware: 'Most people don't understand, the working class, our parents, and other community members need to become aware of these problems'. 'EE is a platform but it needs the people, people can stand up and say something to make people aware, to fight inequality'. This so graphically illustrates how these learners learnt about power and about the politics of organising. The comparison between the COSAS struggles of a decade earlier and the EE interventions would be incomplete without acknowledging the huge differences in resources that each respective movement had access to. EE is very successful in building significant financial resources from both international donors and a strong and loyal community of contributors.

Linda was introduced to EE through one of his teachers, who was a former member of TAC. He recalled the first meeting at his school on 8 May 2008. Unlike the majority of learners at the small initial meeting who were in Grade 9 and Grade 11, Linda was in his final year of school. He recalled that the meeting was held at the EE office and that the youth group had organised transport. At the time he was a little unsure about the organisation, but he described it as a 'good thing' - learning the history of South Africa. During that year the movement began to grow, and after he passed matric he was asked to head the youth group as a facilitator. Linda worked in the first year as a facilitator/intern involved in organising transport for learners to meetings, marches and pickets. During the following year, while he was still working with EE, he decided to rewrite his Grade 12 examination to improve his marks so that he could go to university. As an Organiser his job was to speak to principals, organise learners and engage in organisational activities. In his work with learners he organised a range of activities from very humble jobs like cleaning the school toilets to mobilising for EE campaigns in the city centre. 
Linda described the two major achievements of EE: first, it showed young people that they can make plans and that those plans can be achieved, and second, it showed them how to communicate with a wide range of people, including learners, teachers, principals and officials. He also noted that it was important for the organisation to be based in the working-class township of Khayelitsha and that it is now taking the campaigns to national level.

Nkosi attributed the development of his political consciousness to his grandmother's open and progressive values. He described how his aunts had worried about a gay cousin, while his grandmother was very open-minded about it. EE simply extended and deepened this political orientation towards tolerance and openness.

Nkosi did not understand the links between xenophobia and the wider social issues until he began to work with EE. He now understands the importance of links with other organisations around health and social justice. Nkosi described how his understanding has evolved from the first 500 Broken Windows campaign. The key for him was his participation in the leadership committee in 2009. Like his scout meetings, the committee met every Friday evening to plan and coordinate campaigns. In the early meetings with EE, the learners at his school talked about the problem of not having a Science teacher. They then began to talk about not having a library at school. This led to a wider campaign for school libraries. The next campaign was the late-coming campaign. This required the Equalisers and Organisers to begin communicating effectively with school principals, teachers and learners. In the leadership meetings, the Equalisers learnt how to be assertive without being aggressive. They learnt a great deal about non-violent struggle. Leaders learnt how to speak openly to their peers in these meetings. They began to understand why it is important to avoid rudeness or vulgar language, how to run meetings, how to debate issues, how to manage groups of learners, and how to solve organisational problems.

Nkosi also joined an EE reading group that helped him develop tools for analysing society. Amongst things he recalled reading were books like Orwell's Animal Farm and articles about South African history. In the reading group, they carefully analysed the Minister of Basic Education's speeches. He began to understand the basic analysis of class relations, capitalism and socialism. He was also exposed to analyses of why the suburbs were affluent and the townships were poor, and how this impacted upon educational inequalities. This all made sense to him and it aided his understanding of his own experiences as a learner living in a poor community in Cape Town. This analytical vocabulary also helped him in his studies at university. These understandings were deepened in the course of his meetings with EE activists from Khayelitsha as well as activists from Kwazulu Natal and the Eastern Cape.

Nkosi stressed that EE was not only about criticising the government, but offering an alternative. This is clear in the 2009 library campaign when EE helped build libraries, train librarians and collect books in their bookery. This was to change the nature of the system and demonstrate that schools could and should have libraries and librarians. 
Ayanda had a very different level of understanding of the organisation. Not having come through the ranks of EE as an Equaliser, she joined the organisation with a group of university friends. Ayanda went through the training to become an Organiser. She recalled that the training equipped her to cope with peer pressure, handle high school learners (and their behaviour), not to humiliate them and to speak to them in private if necessary, and to bring out shy people in the group. She facilitates weekly meetings and helps coordinate various EE activities, including calling taxi drivers for the learners' transport, sending bulk SMSs to remind learners of the meetings, explaining how to make claims for the team, making certain that the programme is planned at least two weeks before the meetings, and ensuring that they have read and understood the materials for the meetings. She also assists with planning activities for the EE congresses and workshops.

Ayanda became involved in EE by participating in the production of the EE documentary. Like the earlier experiences that Zami had with the photography workshop, which led to the photograph of the bank of 500 broken windows, EE as an organisation worked with a group of volunteer documentary film makers. As one of the four interns, he was taken through all phases of the film-making process: using the camera, editing, directing, and writing the treatment. They uploaded the film they made on YouTube. The film is titled 'Equal Education: What it means to be an Equaliser'. This film project inducted him into the movement, and through it he became involved in the late-coming campaign and the sleeping-outside-parliament campaign. Since then he has become active in the youth groups, helping them define topics for discussion, planning campaigns and assisting in EE campaigns on university campuses. He told us that involvement in these EE campaigns taught him 'the importance of maintaining good relations with our mothers, learners and the principals'. It also taught him 'to fight for my rights, even if this is difficult'. As he put it, 'We have a right to picket because we are tired of the Minister not responding. They are no longer scared to sleep outside of Parliament or even to get arrested'. In addition to acquiring a sense of the right to have rights, Ayanda also described the benefits of having learnt to speak in public and to assert his rights vigorously without breaking the law.

These accounts of the experiences of Equalisers and Organisers draw attention to the ways in which EE sought to develop the organisational and political skills of its members. The narratives highlight the extent to which EE embodies the principle of learning power. In the campaigns, workshops and meetings activists learnt about power. They began to understand the relative importance of the principal, the district office, the provincial education department and the national Minister of Education. They internalised the lessons of earlier working-class organisations and why other student movements failed to build sustainable campaigns. From participation in political education workshops, the activists began to understand the power of learning. Activists began to understand the value of reading historical accounts 
of struggles and the use of political economy that broadened and deepened their political work. From their engagement in EE projects and campaigns, these workingclass activists learnt to be powerful, came to understand when to stand up to the minister, and to challenge and confront power in ways that did not burn bridges. For instance, at an EE meeting in Khayelitsha attended by the national Minister of Basic Education in 2012, we noted the confrontational style of EE Equalisers and rank-and-file EE members who expressed their profound frustration with the failure of the national department to address problems relating to textbooks, libraries and general school infrastructure. Rather than viewing EE Equalisers as either compliant or resistant, it is necessary to recognise that their responses to authority tend to be highly situational and contextual.

\section{CONCLUSION}

There is little doubt that Equal Education has become a very potent change agent in the South African social justice space. At a national level, its most important victory was locating minimum standards for school infrastructure at the centre of the national debate about education equity.

From the perspective of the individual learner organisers, the study demonstrates that these young activists acquire powerful skills and knowledge through participation in the social movement. Equal Education also provides the Equalisers with access to wider social and political networks. At the most basic level, many learners' first major political awakening came during their interaction with learners from other secondary schools. This shifted their political consciousness, which had previously been confined to competition between high schools over soccer teams and uniforms, to realising that the problems faced at one school were in fact problems faced by all schools in working-class communities. This could be viewed in terms of the classic distinction drawn by $\mathrm{C}$ Wright Mills between private troubles versus public issues. The second level of networks is between Equalisers and Organisers. Although they came from the same social and economic context, the Equalisers had an opportunity to link in with learners who were activists and had also worked out how to access university or post-secondary education. The third level was linkages with the middleclass university students - linkages that would provide invaluable information for social mobility through higher education. Finally, these networks include the wider set of volunteers and supporters, i.e. international exchange student volunteers, middle-class activists, film makers and board members.

Alongside the acquisition of these skills, knowledge and networks, Equal Education also provides Equalisers and Organisers with what can be termed 'empowerment' or learning to be powerful. Empowerment in this context is the experience of identifying a problem, learning to speak confidently and with authority in public spaces, developing a set of strategies and tactics, mobilising, campaigning, 
and finally being successful and then repeating that process. This enables Equalisers and Organisers to realise that they can take control of their collective destiny. Empowerment comes from concrete victories at local, provincial and national level engagement. They can see the links between their own actions and positive outcomes for themselves and the organisation. This also allows them to make difficult personal decisions, e.g. to move from a commerce course at a post-secondary institution to studying politics and history at a university.

So the small acts of empowerment and mundane practices of slow activism facilitated by the EE are often located 'backstage' and they may not, a first glance, seem directly related to the explicit objectives of the organisation to reform and improve public education in South Africa. For instance, they may include individualised benefits to learners such as the acquired capacity to access the 'hidden curriculum' of a middle-class professional habitus and culture. This is evident in the concrete steps that need to be taken to organise 'spectacular' protests such as sleep-ins at Parliament. To ensure the success of such campaigns EE activists have to be able to come up with tactics and strategies, convene planning meetings, take minutes, arrange logistics such as transport, catering and the invitation of journalists to media briefings. They also need to be able to speak publicly. It is these 'hidden' techniques of slow activism that seem, at first glance, to be strikingly different to the spectacular politics of the student protests of 2015. Yet, when one examines the processes leading up to the 2015 student protests, it becomes clear that ongoing organisational labour, often in the form of 'teach-ins' and numerous strategy and tactics discussions, profoundly shaped the form of the spectacular protests that took place at Parliament and the Union Buildings in Pretoria. It is these less visible forms of organisational labour that can make the difference between success or failure. Similarly, the successes of EE's media-savvy social audit and norms and standards campaigns were the outcome of 'backstage' forms of slow activism as well as the social mediation of organisational skills and ways of 'learning to be powerful' that are typically associated with the 'hidden curriculum' of middle class and professional cultural capital and 'soft power'.

But what, if any, systematic impact is EE having in view of what many see as an entrenched crisis in the school system? While beyond the ambit of this paper, an argument can be made that EE has had a very significant impact on the school system by placing the question of the adequacy and equity of school infrastructure at the centre of educational change debates. Government, both national and provincial have responded, albeit, slowly and unevenly.

\section{REFERENCES}

Alvarez, S., E. Dagnino and A. Escobar, eds. 1998. Cultures of politics, politics of cultures: Revisioning Latin American social movements. Boulder, CO/Oxford: Westview Press. 
Angara, H. 2011. The 500 Windows Campaign: A case study of a youth movement for educational resources in South Africa. InterActions: UCLA Journal of Education and Information Studies $7(2)$.

Edelman, M. 2001. Social movements: Changing paradigms and forms of politics. Annual Review of Anthropology 30: 285-317.

Escobar, A. and S.E. Alvarez, eds. 1992. The making of social movements in Latin America: Identity strategy and democracy. Boulder, Colorado: Westview Press.

Fuentes, E. 2009. Learning power and building community: Parent-initiated participatory action research as a tool for organizing community. Social Justice 36(4): 69-83.

Fleisch, B. and S. Robins. 2014. Mediating active citizenship and social mobility in working class schools: The case of Equal Education in Khayelitsha, Cape Town. In Mediated citizenship: The informal politics of speaking for citizens in the Global South. Edited by B. Von Lieres and L. Piper. Palgrave Macmillan.

Hargreaves, A. 2002. Sustainability of educational change: The role of social geographies. Journal of Educational Change 3(3): 189-214.

Mbali, M. 2013. South African AIDS activism and global health politics. Hampshire, England: Palgrave MacMillan.

Melucci, A. 1989. Nomads of the present: Social movements and individual needs in contemporary society. Philadelphia: Temple University Press.

Nixon, R. 2006. Slow violence, gender and the environmentalism of the poor. Journal of Commonwealth and Postcolonial Studies 13(14.1): 14-37.

Stun grenades were used to 'defuse situation' - cops. News24, 6 March 2015. http://www.news24. com/SouthAfrica/News/Stun-grenades-were-used-to-defuse-situation-cops-20150306 (accessed 1 March 2015).

Oakes, J. and J. Rogers. 2006. Learning power: Organizing for education and justice. New York: Teachers College Press.

Oakes, J. and J. Rogers. 2007. Radical change through radical means: Learning power. Journal of Educational Change 8(3): 193-206.

Robins, S. 2008. From revolution to rights in South Africa: Social movements, NGOs and popular politics. London: James Currey Publishers; Pietermaritzburg: University of KwaZulu Natal Press.

Robins, S. 2014. Slow activism in fast times: Reflections on the politics of mass media spectacles after apartheid. Journal of Southern African Studies 40(1): 91-110.

Salinas, D. and P. Fraser. 2012. Educational opportunity and contentious politics: The 2011 Chilean student movement. Berkeley Review of Education 3(1).

Shirley, D. 1997. Community organizing for urban school reform. Austin: University of Texas Press.

Shirley, D. 2009. Community organizing and educational change: A reconnaissance. Journal of Educational Change 10(2-3): 229-237.

Touraine, A. 1981. The voice and the eye: An analysis of social movements. Cambridge: Cambridge University Press. 
Touraine, A. 1985. An introduction to the study of social movements. Social Research 52(4): 749-787.

Warren, M. R. and K.L. Mapp. 2011. A match on dry grass: Community organizing as a catalyst for school reform. New York: Oxford University Press. 